Haunted Archives: Presence and Absence in the Audio-visual Record of Conflict in Bosnia-

\title{
Herzegovina
}

Lennaart van Oldenborgh

DOI:10.15664/fcj.v19i0.2385

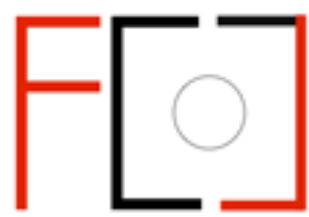

Frames Cinema Journal ISSN 2053-8812

Issue 19 (March 2022)

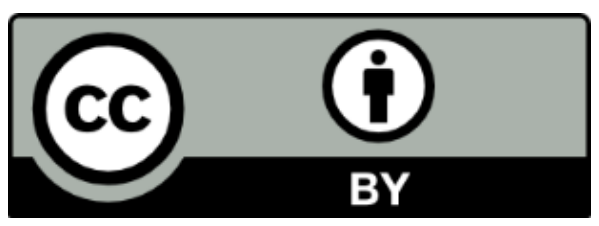


Frames Cinema Journal, Issue 19 (March 2022)

\section{Haunted Archives: Presence and Absence in the Audio-visual Record of Conflict in Bosnia- Herzegovina}

Lennaart van Oldenborgh

\section{Introduction}

As a film editor working primarily in broadcast documentaries, I have often wondered why more raw rushes are not preserved in audio-visual archives. Especially when it comes to news or documentary footage of historically significant events, rushes have a value beyond what a filmmaker or news editor deems significant at the time, and new insights can be gleaned from renewed scrutiny of audio-visual details that may at first have been considered irrelevant or even undesirable. To explore this idea, I am concentrating on news coverage of the siege of eastern Mostar, in southern Bosnia-Herzegovina, between May 1993 and March 1994. Specifically, I examine the burst of media attention in the days around the arrival of the first UN aid convoy on 21 August 1993. Comparing some of the edited accounts of that time with some of the surviving raw footage, I argue for the value of preserving and archiving raw footage of such events, even if the footage may initially appear irrelevant or trivial. It is my contention that the experience of rushes in the archive is qualitatively different from the experience of edited films and reports, in the sense that they often contain unintended images that have the potential to shock in their incongruity, to reveal something of the biases and aims of the filmmakers, and to convey a sense of the "presence" of a past event beyond the experience of an edited account, which is more stringently mediated through the editorial and narrative control of the filmmaker.

The siege of eastern Mostar in 1993-94 was noteworthy in the context of the conflict in BosniaHerzegovina both for its close and highly destructive urban combat, and because the main hostilities were between the HVO (the Bosnian Croat militia) and the ARBiH (the Bosnian government's army, dominated by Bosniaks), but did not involve the VRS (the Bosnian Serb militia). ${ }^{1}$ The conflict between the HVO and the ARBiH at the time is to be understood in the 
context of the Vance-Owen Plan of 1993, which proposed the division of Bosnia-Herzegovina into ethnic-majority cantons, effectively rewarding ethnic cleansing. According to this plan, the canton containing Mostar would be majority Croat, so the HVO felt justified to assert their authority over all of it, which was resisted by the Bosniaks of Mostar, who were largely concentrated in the east of the city. ${ }^{2}$

At the time of the siege, from the middle of 1993 to early 1994, I worked as editor and second cameraman for the video unit of the Press and Information department of UNPROFOR, the UN peacekeeping mission in the former Yugoslavia. One set of rushes from Mostar on 21 August 1993 was shot by a colleague of mine at the time. This was preserved in the "UNTV collection" in the Imperial War Museum, London, and is one of my main sources. As part of my wider academic research into the audio-visual record of the siege of Mostar, I have also recently visited Mostar, and interviews with a number of survivors of the siege have informed my insight into the context. ${ }^{3}$

\section{Commercial news archives and their exclusions}

According to a well-worn maxim, "journalism is the first rough draft of history". ${ }^{4}$ While this is usually applied to written journalism, the emphasis on the construction of history as a narrative the draft - is not incidental, and applies to news in all its forms, including television news journalism. In my work as a film editor (like most editors, I have found that, in practice, editing is primarily focused on narrative), I have often made use of archival footage to illustrate or evoke historical scenes, and have noted how much broadcast production relies on commercial news archives (AP and Getty Images are currently dominant among these), rather than film museums or repository archives (such as the BFI or the British Library) to source this material. ${ }^{5}$ The great majority of entries in these commercial archives consist of edited films or news features (often referred to as "stories"). Listings of raw rushes are rare. 
Commercial news archives are not actually archives in the strict definition of the word, which, etymologically, is associated with official record-keeping of the state. ${ }^{6}$ Indeed, according to Michel Foucault the archive is not a "library" or a physical collection of things, but it is first and foremost a system of enunciation. ${ }^{7}$ Under this logic, commercial news archives would have to be characterised as "collections", even if most of them describe themselves as "archives". 8 For the sake of simplicity, I will stick to this self-designation and refer to them as "archives" as well, with the understanding that the criteria that regulate their contents are part of this designation.

Like me, the media archaeologist Trond Lundemo is interested in the question what gets excluded from the archive beyond the formal requirements that regulate the archive. He points out that archiving is not about storage but about selection and that all exclusions create "gaps and lacunae in the preservation of the past", which means that they are, by their very nature, political exclusions. ${ }^{9}$ In privately owned and managed archives of (photographic) moving images, many decisions of exclusion are driven by corporate, commercial criteria that are subject to the logic and contingencies of the marketplace. For example, the majority of archived analogue items in these archives tend not to be digitised: the archives generally work according to what Wolfgang Ernst calls a model of "digitization on demand", only reacting to current needs. ${ }^{10}$ To make matters more complicated, these archives themselves can be traded as capital investments, and often are. Thus, they may fall under different commercial, and therefore archival regimes at different times in their history. ${ }^{11}$

Matthew Butson of Getty Images' Hulton Archive, confirmed in a conversation about digital conservation that the investment of digitisation is only made for at most 5-10\% of a collection, focusing on images that are predicted to generate an income from licenses. ${ }^{12}$ In my own experience it is often the first client requesting an as-yet undigitised entry who pays for the digitisation. ${ }^{13}$ 
The question of archival exclusion shifts from one of regulatory exclusion to one driven by storage and access: analogue sources are more difficult to access, and run a higher risk of becoming obsolete or falling into disrepair. ${ }^{14}$ This raises the question of the political implications of such exclusion. Implicitly, the default mode of audio-visual media is attrition, but obsolescence is ideological, in that it submits to a technological teleology in which sequence is interpreted as progress: newer technology is always somehow considered to be "better". In addition, the marketisation of the archive is an ideological disposition in itself, favouring a capitalist model of image preservation. In this model, history itself is not seen as a shared cultural heritage, or a kind of commons, but as the raw material for commodification, according to which historical artefacts become objects of economic exchange.

Finally, the strong tendency to preserve only finished films means that the editing room itself is a significant site of archival exclusion, where the criteria of selection are driven by considerations of editorial policy (and bias), narrative convention and the filmic grammar of montage, rather than the legal-political considerations of the state archive, or the preservationist tendencies of the historical archive.

\section{The feedback loop of historical footage}

The question then arises: what do these exclusions of historical footage - on commercial as well as filmic, narrative and editorial grounds - do to our view of history? Or perhaps more pertinently, what do they do to our collective memory of that history? We all know the phenomenon of the Second World War being "remembered" in black and white by subsequent generations, given that their knowledge of the time was mediated through black-and-white newsreel footage. ${ }^{15}$ There is of course an ongoing debate about the relations between history and memory, and in the 1980s Pierre Nora introduced the idea that collective memory can be externalised in places, buildings and objects, in what he called "lieux de mémoire", or "places of memory". As a result, we can 
speak of moving images as mnemonic artefacts: "symbolically mediated" memories that have the power to re-implant themselves in their viewers as a type of personal memory, even if their experience was a mediated one. ${ }^{16}$ Consequently, historical events can be vividly "remembered" by people too young to have lived through them. ${ }^{17}$ Such symbolically mediated collective memories of historical events are a staple of what Aleida Assmann calls "national memory" or "myth", which are crucial in the formation of national identifications. ${ }^{18}$

The memories contained in audio-visual archives are haunted by multiple gaps and absences, however. Filmic images, as Mary Ann Doane notes, are already doubly haunted: any photographic image, as index, is haunted by the absence of the referent that left its imprint on the photosensitive surface; moving photographic images are also haunted by the lost time between individual frames (necessary to create the illusion of temporal continuity), a haunting that is echoed by the cut, which represents the lost time between shots. ${ }^{19}$ To this double haunting I propose to add a third: every cut in an edited film is haunted by lost footage, rushes that were shot but did not make the final edit. Consequently, those rushes are much less likely to have been archived or preserved, and may be neglected, or often lost altogether.

The perception of history as mediated by documentary film is haunted by such neglected or lost footage. Philip Rosen points out the parallels between historiography and the practice of documentary film, in which the "sequenciation" of indexical remnants of the past (rushes) produces a coherent narrative, just as historiography extrapolates narratives from surviving historical remnants or documents, which involves an inevitable filling in of missing parts. ${ }^{20}$ Documentary films, insofar as they are placed into various archives, in turn become "documents" for future historiography and documentary filmmaking. This reveals the outline of a feedback loop: the first edit eliminates all the rushes that did not make the first cut and is placed in the archive as a cut film; this film may then be the source for another film, which may only select the most salient 
or sensational footage from the first edit, and is then placed in the archive as a more recent cut film, which may then be the source for a third film, etc. This tends to produce a diminishing pool of historical images, edited down and re-mediated with each cycle, so the gaps between the images increases while any surviving rushes are increasingly likely to disappear with the attrition of time.

This chimes with the use of archival images from commercial archives in practice according to Phil Clark, who works as film researcher in the broadcast industry. ${ }^{21} \mathrm{He}$ calls it a "self-fulfilling prophesy": "well-known" images of a historical event (the ones that have appeared in many films) are more likely to be easily available from the archives (i.e. already digitised in current format), and are more likely to be recommended by the archives' in-house "researchers" (often in effect sales agents), whose job it is to sell the largest amount of licenses in the shortest amount of time. These recommendations are often accepted by time-starved film researchers with tight deadlines, and the same images are therefore more likely to re-appear in new films covering the same event. ${ }^{22}$ A similar feedback loop was described to me by Butson of Getty Images, with the difference that he attributed it to the interaction between search algorithms and the relative laziness of clients: images that have been sold more often get a higher ranking in the algorithm, and therefore appear higher up in searches sorted on "relevance" or "popularity". At the same time, clients rarely stray past the first six pages of search results, reinforcing the popularity of the highly ranked images. ${ }^{23}$ Hence one can speak of a "feedback loop of historical footage".

The diminishing pool of "iconic" images, that condense complex historical events to easily narrated, and memorable form, are highly instrumental in those collective, symbolically mediated memories that form the basis of political and national identifications. ${ }^{24}$ The editing room as a site of archival exclusion puts narrative at the heart of the formation of such identifications, and of the political exclusions that they entail: hence the exclusion of rushes from the archive may reflect 
something of the exclusion of ambiguity in the historical narratives that help to shape national identity.

Memories of conflict play an especially important role in the formation of such identifications, and play a role in the potential for renewed conflict. The potential of contested histories to reignite conflict is distressingly illustrated by the current threats to the unity of Bosnia-Herzegovina, which were sparked by the Bosnian Serb leadership's rejection of a law that would ban the denial of the genocide in Srebrenica. ${ }^{25}$

At the same time, the feedback loop of historical footage tends to strip images of their ambiguity, or what Dai Vaughan calls images' capacity to "exceed their contribution to any given meaning $[\ldots]$ in the generation of new meanings oblique, peripheral, or even antagonistic to the text as understood". ${ }^{26}$ Vaughan's primary concern is with the preservation of ambiguity in his edited documentary films, and he describes succinctly how the meaning of images is never exhausted. However, this does not apply equally to all footage: both Pasolini and Doane draw attention to the contingency of the "long take", which resists being fixed in its meaning, and, of course, raw rushes always consist of longer takes than the films that are edited from them. ${ }^{27}$

Speaking about what is lost with the loss of rushes means speaking about absence, and becomes inevitably speculative. In his discussion of four rare photographs of Auschwitz, taken from within one of the crematoria during its time of operation in 1944, Georges Didi-Huberman proposes an almost psychoanalytic approach to photographic images: "should we not treat the impurities, the lacunae of the image, as we have to treat the silences of speech, which is to unravel them, to struggle with them?"28 In this proposal he is clearly inspired by the method within trauma studies that treats the silences in witness testimony as significant symptoms of the trauma that cannot be articulated. ${ }^{29}$ What is significant for my purposes is that Didi-Huberman appears to suggest we 
might treat photographic images themselves as symptoms, as lacunary traces of a greater context, some of which may still be inferred from them.

Arguably this is exactly what is practiced by the more recent, overlapping methods of architectural forensics, data forensics and image forensics. For example, the project Black Friday by Forensic Architecture (FA) displays an exemplary attentiveness to the gaps between moving images: fragmentary moving image phone recordings of Israeli airstrikes on Rafah in the Gaza Strip on the last day of the 2014 Gaza war are placed within a 3D model of the urban environment, and along a timeline of the "real time" of events in order to extrapolate exactly when and where the explosions took place. ${ }^{30}$ This allowed FA to reconstruct the wider context of the bombings both spatially (outside of the frame of the recordings) and temporally (between the individual takes of the recordings).

In my wider research into moving images that document the siege of Mostar in 1993-94, I have been struck by how unevenly any documentation is distributed along the 10 months of the siege: months went by with virtually no image production at all, while occasionally the "media spotlight" fell on Mostar, and dozens of hours of footage would be produced within a relatively short period of time, mostly by journalists of international news broadcasters. From those dozens of hours, usually only minutes can be found in the archives as news features or news agency satellite feeds. Unusually, however, I have been able to locate some of the raw rushes from the intense media attention that surrounded the first humanitarian convoy to arrive in the enclave of eastern Mostar on 21 August 1993. To "struggle with the gaps" in the historical record of this siege, I examined those rushes in relation to the edited news features made around the same event, on the wager that an instance in which rushes are not lost, and made accessible to research, may be able to approximate what effects an actual loss would imply in other instances. In other words, what is at stake in this study is the idea that unexpected elements within these rushes may reveal some of the 
kinds of historical insights we might have lost with other rushes that ended up on the cutting room floor in the process of narrativising the conflict.

\section{The Mostar siege in the archives}

For the purposes of this article, I am concentrating on international news coverage of the Mostar siege in the days around 21 August 1993. The news "ecology" at that time and place was of course determined by the state of technology, and the contemporary practices of the "news industry". In the 1990s, this meant that "field reports" were generally shot on fairly bulky, shoulder-mounted cameras recording to Betacam SP analogue Standard Definition tape. ${ }^{31}$ These field reports would often be sent to international broadcasters via satellite. Because high-bandwidth satellite links were expensive, they would be edited down before being offered for sale via the satellite network. From searches in the catalogues of the news archives, it is clear that such "satellite packages" are often the form in which these materials were archived, especially by the news agencies.

Due to the military encirclement of East Mostar, no international news crews managed to gain access to the enclave for the first three months of the siege, and there was little to no reporting on the situation. When the UN negotiated access for its first convoy for months, on 21 August 1993, it arrived with a small consignment of medical aid, and with a number of international news crews in tow. Rather remarkably, barely a day earlier, a CNN crew had arrived on foot and horseback, via an arduous, three-day trek over the mountains from Sarajevo. ${ }^{32}$ A few days later, the BBC correspondent Jeremy Bowen arrived with a crew via the same route. Late on 25 August a second UN convoy arrived, this time with a number of trucks filled with food aid, and again, several news crews in tow. This convoy was blockaded in by the local population, and was only able to leave a few days later when a semi-permanent UN office was established. ${ }^{33}$

Due to these convoys, the international media spotlight was briefly on the situation in Mostar, roughly in the period between 19 and 31 August 1993, and a large amount of news reports were 
produced. A search for "Mostar" between 19 and 31 August 1993 in various news archives yielded a relatively large number of items, the great majority of which were "offline", meaning they had not yet been digitised from their analogue sources. For example, Getty Images listed seventy-four items, consisting of eighteen duplicates, eighteen (discrete) items originally from the ITN archives, twenty from BBC archives and eighteen from NBC News archives. ${ }^{34}$ Only 5 items (all from ITN) were digitised and online, none of which contained footage of the actual Mostar enclave, but mostly from the nearby UN base in Međugorje. ${ }^{35}$ The CNN Collection listed three items, all offline, but a request over the phone threw up two additional edited items, and nine reels of raw rushes, one of which was a duplicate. ${ }^{36}$

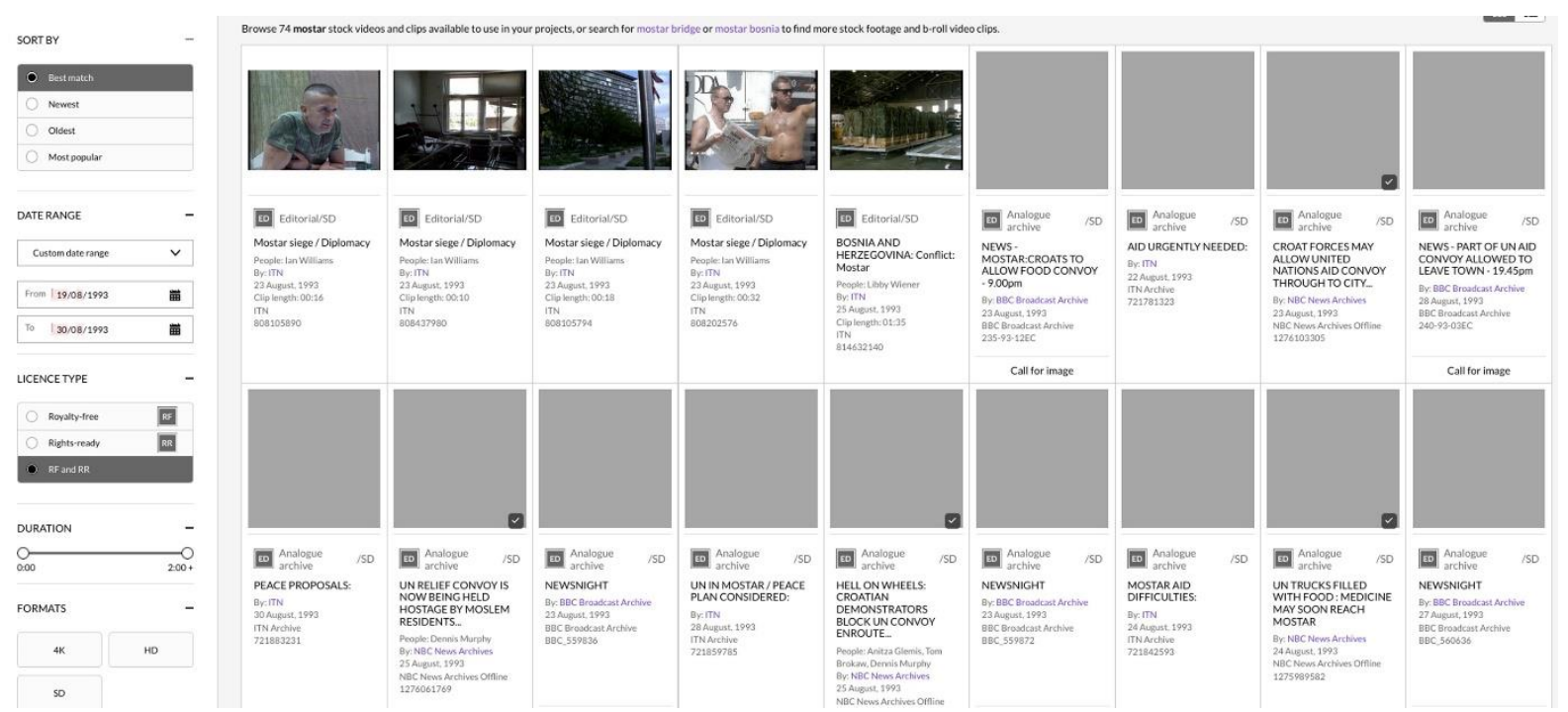

Figure 1: Getty Images search. Of 74 items, five have been digitised; others are marked "Analogue archive". https://www.gettyimages.co.uk/videos/mostar?assettype=film\&begindate=1993-08-19\&enddate=1993-0830\&offlinecontent=include $\&$ phrase $=$ mostar $\&$ recency $=$ daterange $\&$

In addition to the news cameras present, the two UN convoys were documented by a camera from the Press and Information department of UNPROFOR. ${ }^{37}$ Six reels of the UN rushes (two from the first convoy, four from the second convoy) and two edited items (a 10-minute video structured as a press release, using rushes from both convoys, and a feature entitled "Sisters of Mostar", which was edited a year later from the second convoy rushes) are preserved in the UNTV collection in the Imperial War Museum (IWM) in London. ${ }^{38}$ In the UN rushes of the first convoy on 21 August 
1993, at least four other cameras can be discerned: the CNN crew, a TVE (Spanish TV) crew, a Spanish army cameraman and one unidentified crew. ${ }^{39}$ A brief, impromptu interview in the street with the UNPROFOR spokesman, Cedric Thornberry, is covered by at least three cameras. ${ }^{40}$

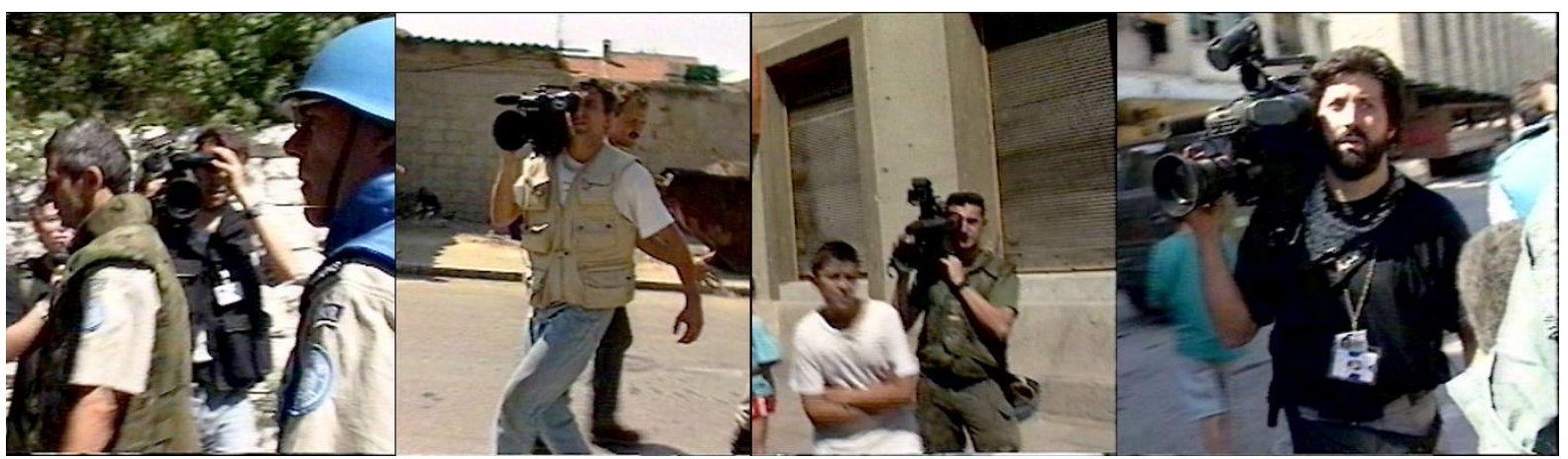

Figure 2. Frame stills showing other cameramen in the UNTV rushes of Mostar on 21 August 1993, currently held by the Imperial War Museum, London. (C) United Nations (IWM UNT 933)

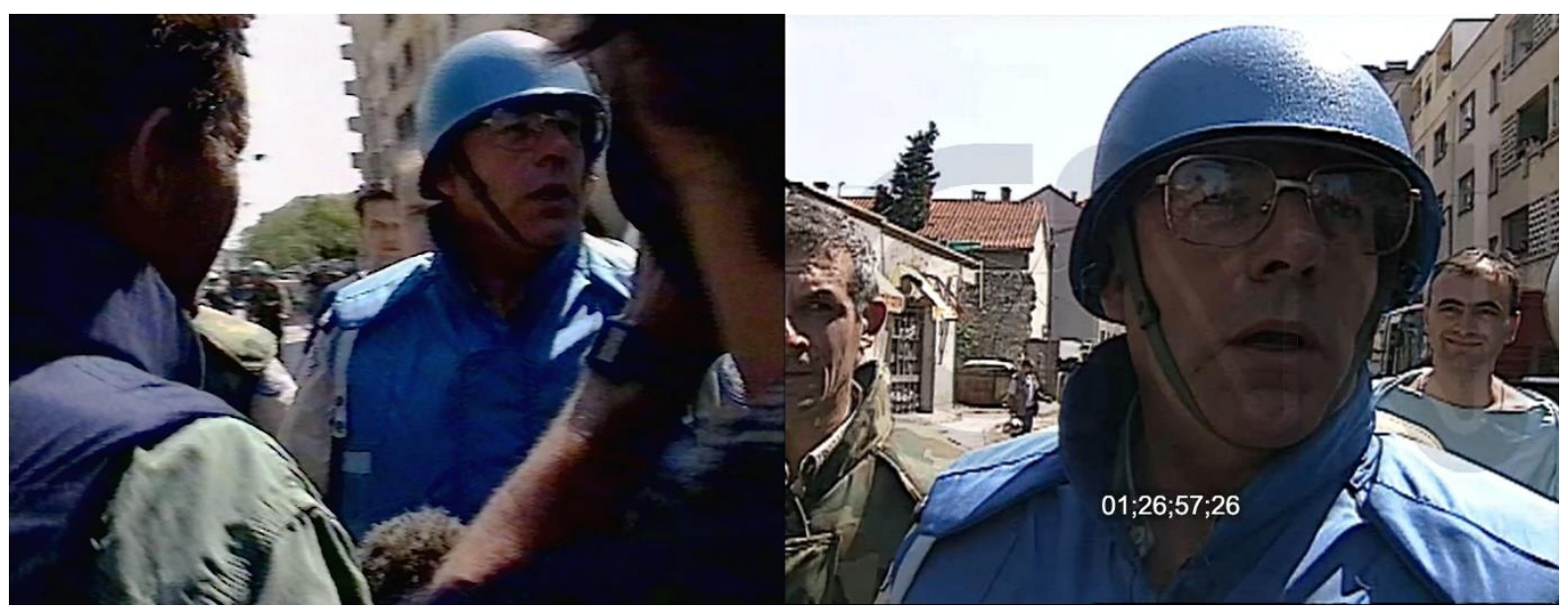

Figure 3. The same moment in the interview with Thornberry from both the UNTV and CNN rushes. (C) United Nations (IWM UNT 933) and CNN Collection (Sadler and Biello FC7904).

\section{Comparing rushes with edited reports}

The interdependence of news organisations and NGOs, and the tendency of the news media to produce events, tend to have the effect that news crews travel in packs, and certain news events can turn into a "media circus". ${ }^{41}$ The sudden accessibility of East Mostar, and the drama of the severe siege it was living through, created a version of a media circus in East Mostar in late August 1993. The contrast with the almost complete lack of audio-visual material from the preceding three months is arresting. The slow aspects of the violence of a siege do not lend themselves to news reporting in the way sudden, spectacularly violent events do, so sieges are often represented 
through specific events, like the arrival of a humanitarian aid convoy. The effect of this concentration of media visibility is that the majority of the images coming out in the various news reports look very similar, not only because they are largely shot in the same location at the same time, but also because they follow similar conventions in the format of news features that were current at the time.

Familiar features from all the news coverage include traveling shots through no-man's land into the enclave, cutaway shots of ruined buildings and devastation, aid being unloaded and packed into storage, wounded people in the make-shift hospital, a short interview with a UN or NGO representative (more rarely with a local representative), and local residents crowding around the UN and aid vehicles in the street. From interviews I conducted with survivors of the siege, it became clear how many of those images are coloured by the fact that they are produced in the midst of the media circus. For example, at most times during the siege, it was extremely dangerous to be out on the streets, and residents of east Mostar would only come out of the cellars in wellsheltered areas, running past any exposed areas, even spacing themselves out by $30 \mathrm{~m}$ so that not more than one person would be injured or killed by a single grenade. ${ }^{42}$ The fact that the convoy itself was in town meant that the HVO (the Croatian militia besieging eastern Mostar) would largely be holding fire, producing a welcome break for the population, and creating, certainly for the children, something of a carnival atmosphere. In this case, the familiar question about the influence of the presence of the camera on the pro-filmic becomes a question not so much about the presence of a single camera (although in some shots this plays a role as well), but more about the presence of the entire media circus accompanying the convoy, that radically changed the street view of the enclave. The exception is one BBC report from Jeremy Bowen, which was shot when he arrived in the days between the two convoys: his report shows more empty street views, even while the narration states that the streets are calmer than usual, given a "lull" in fighting between the two convoys. ${ }^{43}$ 


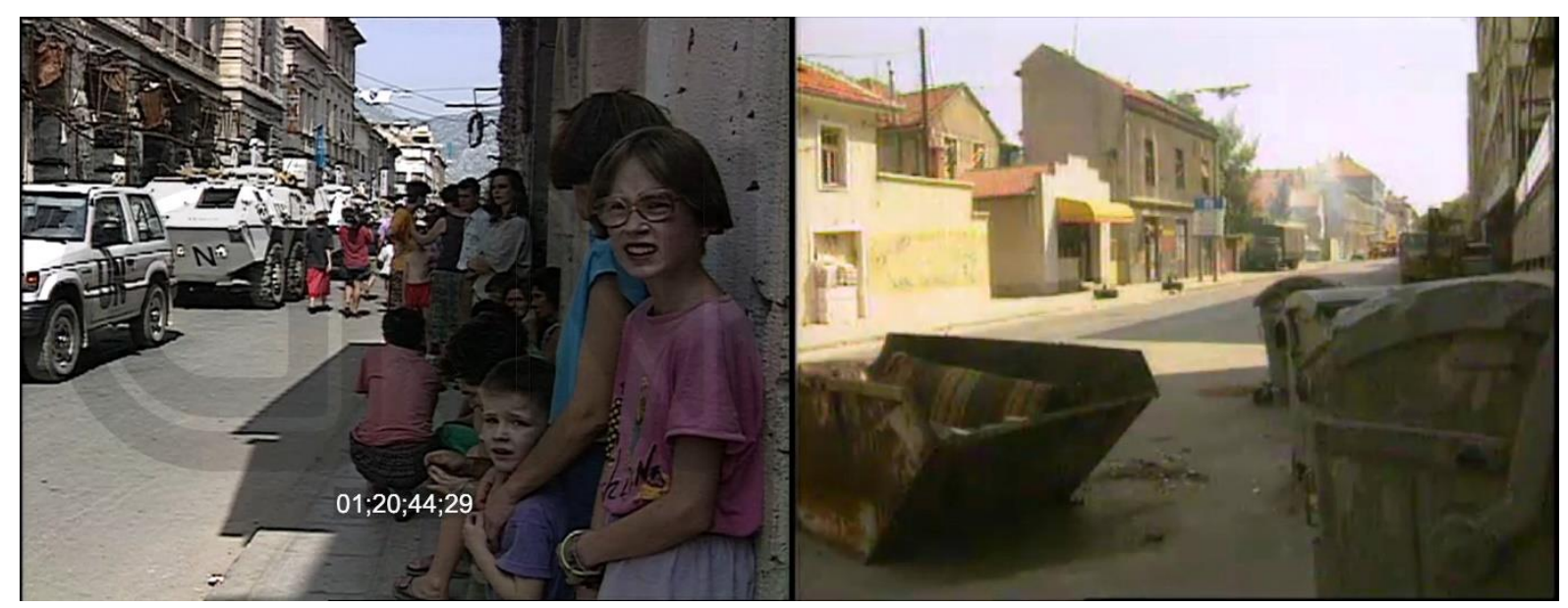

Figure 4: Marshall Tito Street in Mostar, crowded when a convoy is in town (CNN rushes), and almost empty in a BBC report. CNN Collection (Sadler and Biello FC7904) and BBC Broadcast Archives (Bowen, BBC News 6pm).

A general focus on children among the wounded in the hospital reveals a preoccupation with the humanitarian aspects of the story. This falls largely within the framing, widespread in the coverage of the conflict in Bosnia, of the local population as "victims" and the UN and NGO officials as "saviours", even though in Mostar the local population managed to keep up a significant level of organisation against tremendous odds. ${ }^{44}$ One effect of this kind of framing is to downplay the agency of the combatants as political actors, distinguishing only, or at least primarily, between perpetrators and victims.

Two short edited reports from CNN reporter Brent Sadler provide a case in point, when viewed against the rushes that were used to cut them. The reports are dated 21 and 22 August 1993, and most of the material was shot on 21 August, the day of the first convoy. The first report, titled "MOSTAR AID", focuses on the delivery of medical aid to the makeshift hospital in the enclave, cut out of chronological order for narrative purposes. ${ }^{45}$ The only interview is with Cedric Thornberry, and the report includes a scene of Thornberry visiting the hospital. The second report is titled "MOSTAR MUSLIMS" and also contains shots of the hospital, without UN officials this time but with a brief interview with "Dr Mujic". ${ }^{46}$ It starts with shots of the mountain trail which the CNN crew used to enter the enclave, and contains several shots of devastated buildings, street 
views and a bridge in Mostar, all empty of people. It ends on a piece to camera by Brent Sadler from Sarajevo.

The untransmitted CNN rushes contain a number of elements that would not have fitted into the narrative focus of the two edited reports, and presumably were left out for that reason. There are many shots of the physical destruction near the front line (some of which were used in the second CNN report and in a BBC report of 23 August), some of them containing soldiers and unidentified men in civilian clothes. ${ }^{47}$ There are actual front-line shots, traveling along a path cut through the inside of an apartment block, peeking through look-out points at front-line positions, and showing soldiers pointing their rifles through openings between sandbags. There are a few brief interviews with soldiers and with two men in civilian clothing; the questions are posed through an interpreter but the answers (in BHS) are not translated back. ${ }^{48}$ The answers focus on the hardships of life under siege, but the soldier also reveals a certain confidence, saying they are not short of weapons and ammunition, and the fighters are highly motivated, eager to rid the city of "those extremists" as soon as possible. There are also multiple takes of a piece to camera by Sadler in front of the burned-out shell of Tito's villa on the Neretva River, in which he comments on the relentlessness of the fighting ("No mercy is expected, none given. Life hangs on a thread"). ${ }^{49}$ To my knowledge, this was never used in a news report. It appears that the $\mathrm{CNN}$ crew gathered enough material for a "military story" about the fighting on the urban front line of Mostar, but that this approach was abandoned in favour of stories that were focused on humanitarian issues (the aid convoy, the hospital). 


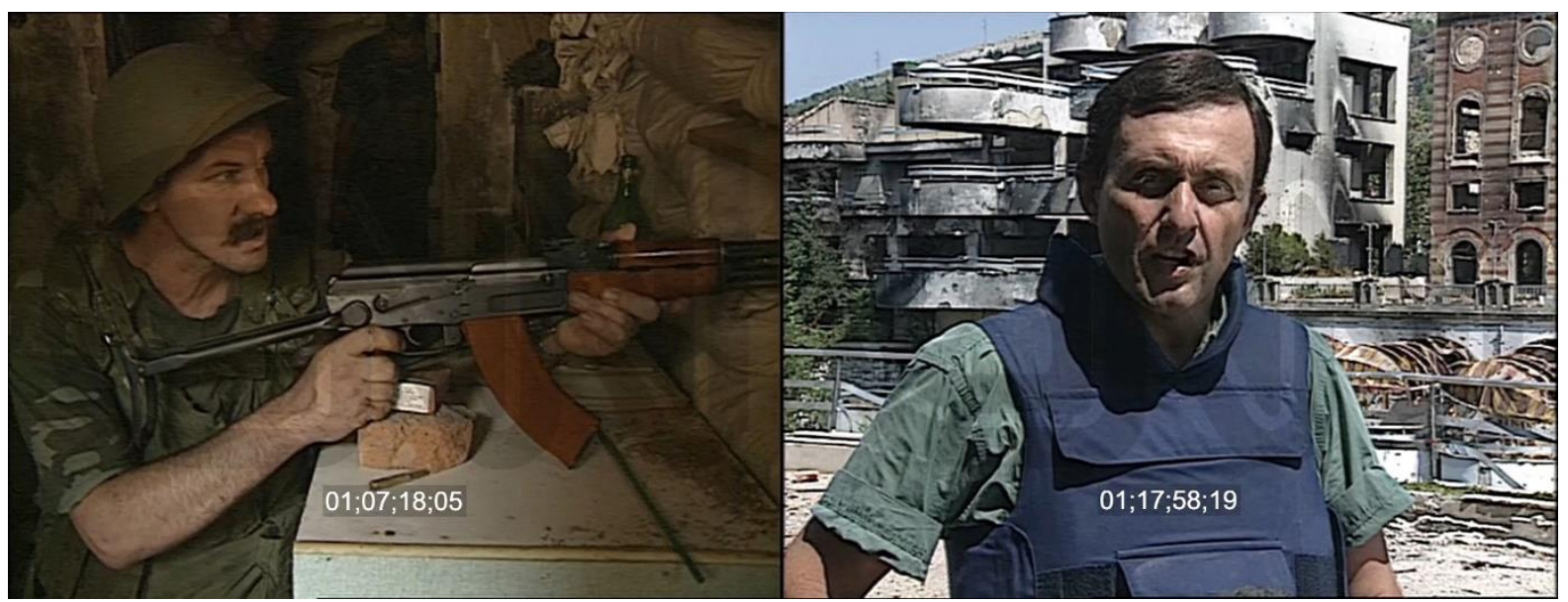

Figure 5: Unused scenes from the CNN rushes. CNN Collection (Sadler and Biello FC7904).

The BBC report from 23 August, which makes use of some of this CNN footage, briefly mentions political aims in the last 20 seconds of the report, but not in a way that all of the residents of East Mostar would recognise. ${ }^{50}$ The commentary suggests an equivalence of ethno-nationalistic aims ("the Croats insist Mostar is the capital of their self-declared Bosnian Croat state; the Muslims are battling to claim it as part of their rump-Muslim state"), which ignores the fact that the Sarajevo government had at least the stated aim to be the government of all citizens of Bosnia-Herzegovina, regardless of their sectarian affiliation, and not just of a "Muslim state". ${ }^{51}$ Interestingly, of the exfighters I've spoken to in Mostar over the course of my research, the majority described themselves as "anti-fascist" fighters, pitted against the "fascist" Croatian HVO, many of whose members openly celebrated the Ustashe, the Croatian fascists allied with the Axis powers in the second world war. ${ }^{52}$ The Titoist Partisan past was, and is, openly celebrated by these "anti-fascist" fighters, and still today the division in Mostar appears not necessarily as an opposition between Bosniaks and Croats (notably some Serbs and Croats joined in the defence of the East Mostar enclave), but equally as an opposition between those who reject the Partisan past (and often celebrate the Ustashe), and those who celebrate it. ${ }^{53}$

Western journalistic representations of the Bosnian conflict typically fall into two types: the "Balkan discourse", sometimes also called the "ancient hatreds thesis", that views the conflict as 
an "ethnic conflict" based on deep historical, even "tribal" hatreds; and a "genocide discourse" that characterises Bosniaks (and sometimes Croats) as victims of Serb genocide, with implicit reference to the Holocaust. ${ }^{54}$ The "Balkan discourse" is considered by many scholars to be based on a "Balkanist" stereotype that views the region as endemically riven by irrational, ethnic passions and conflicts. ${ }^{55}$ The reports discussed here appear to mix elements of both these discourses: their insistence to use ethnic identifiers falls into the "Balkan discourse", while the apparent focus of Bosniak citizens as the victims of violent ethnic cleansing aligns them with the "genocide discourse" (which, in my experience, is the view that most journalists subscribed to on a personal level). What both of these discourses tend to elide, however, is a clear representation of the political aims of the combatants, which could be divided between an ethno-nationalist conception of citizenship and belonging (represented by the Serb and most Croat militias and political leadership) and a civic one (largely represented by the Bosnian Army and government, certainly in east Mostar). ${ }^{56}$

The focus on the humanitarian angle also speaks to a time in the 1990s when "humanitarian intervention" as an idea was actively discussed, and even promoted in the international arena. Robert Meister has characterised this as an era of Human Rights Discourse, in which violence in itself is considered evil (and not a potentially legitimate means to a political end), and therefore something to be prevented in all circumstances. ${ }^{57}$ After the end of the Cold War, rather than as an aim to fight for, human rights are seen as needing protection from violation, which has the effect of maintaining the status quo and ultimately justifies a purely utilitarian policy that pursues the "least of all possible evils". ${ }^{58}$ In the context of the conflict in Bosnia-Herzegovina, the international focus on the "tragic" humanitarian aspects of the conflict, said to be based on hatreds that were "centuries old", served the political purpose of emphasising the futility of any further intervention. ${ }^{59}$ In May 1993, the Clinton State Department went so far as to urgently request evidence of Bosniak atrocities in order to confer equal blame for atrocities on all sides.$^{60}$ Not only 
did the deflection from the "genocide discourse" prevent international obligations to intervene under the Genocide Convention, but the refusal to engage with actual political aims also prevented any political pressure to take sides in the conflict, which may equally have been a cause for more active intervention.

The portrayal of humanitarian agents as "saviours" echoes the classic cinematic trope of the "white saviour" in which a white protagonist is the necessary agent of rescue or resistance for a group of deserving but incapable non-whites. ${ }^{61}$ Catherine Baker shows that the racialisation of the conflict in Bosnia throws up multiple contradictions: not only were many peacekeepers non-white while Bosnians are almost exclusively white, but also the main vector of "othering" in the Western Balkans runs between a (north-western) Europe and a (south-eastern) Balkans, in which each group tends to view themselves as the last "antemurale" bulwark of modern Europe against a chaotic, oriental and pre-modern Balkans. ${ }^{62}$ This configuration is described by Milica BakićHayden as "nesting orientalisms". ${ }^{63}$ But as Baker points out, this shifting placement of people at a distance from Europe and modernity is also a racialising measurement, which places "saviour" narratives in the news reporting on humanitarian missions in Bosnia within the "white saviour" trope. $^{64}$

There is a final element that appears in both sets of rushes that definitely would never have made it into any edited account, but which I believe deepens our understanding of the nature of the international involvement in the Bosnian conflict in retrospect. In both sets of rushes there are moments when the crew, the makers of the rushes, are joking and joshing around with the camera. At the beginning of the first CNN rushes tape, evidently on the way to the Mostar enclave, we see reporter Brent Sadler standing on top of CNN's light-armoured vehicle by a fruit tree in a field, doing a mock piece to camera "I'm in Bosnia picking plums, the Croats are over there, the Serbs are over there, and who's over there... oh yeah the Muslims are over there" ${ }^{65}$ In the UNTV reels 
from 21 August, two of my ex-colleagues from the UNPROFOR P\&I department occasionally lean into the camera to make a quip with the punchline "psy-ops is looking out for you". ${ }^{66}$ At the end of the second reel, in the aircraft back to base, one of them holds up a note to the camera with a cryptic message which he proceeds to stuff into his mouth. ${ }^{67}$

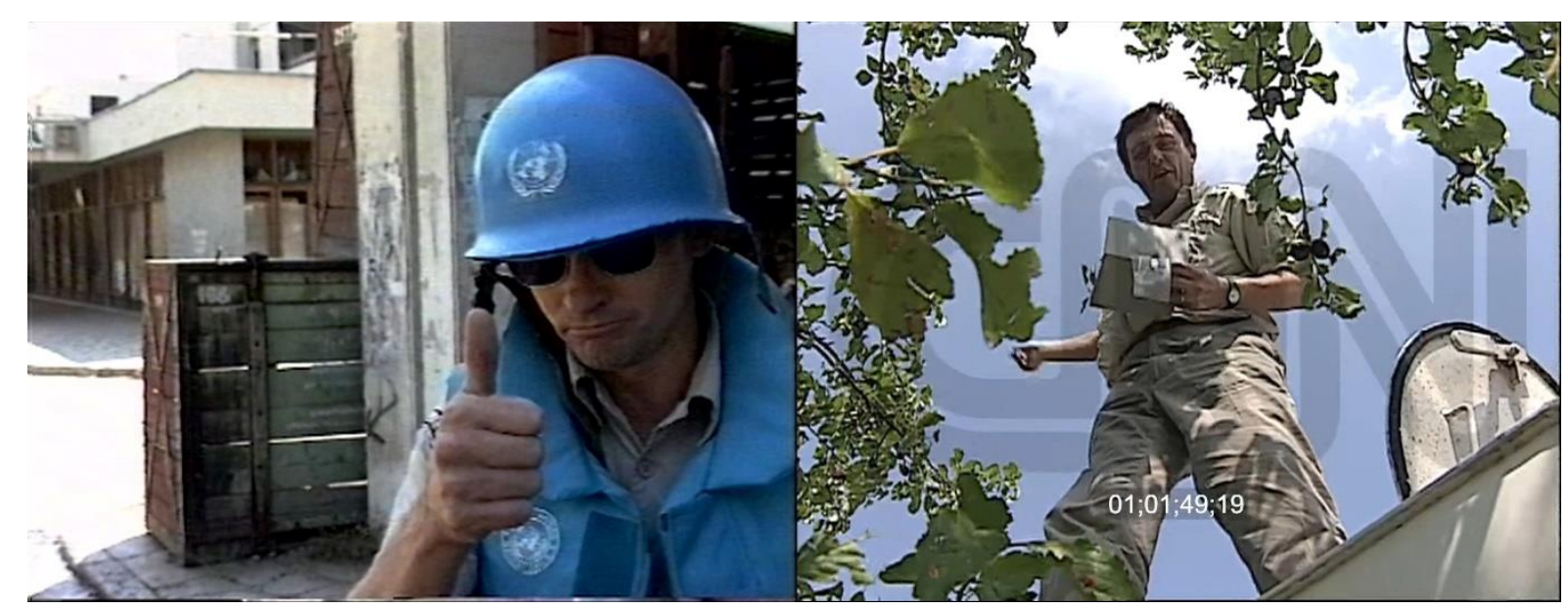

Figure 6: Joking to the camera in the UNTV and CNN rushes. (C) United Nations (IWM UNT 933) and CNN Collection (Sadler and Biello FC7901).

In the experience of viewing these rushes, the incongruity and apparent lack of seriousness of these passages come as something of a shock. ${ }^{68}$ They were clearly not meant to be published or seen by anyone "outside the office", and resemble "home movies" in the sense that they were made for private consumption, and their preservation might even be an embarrassment to their makers. ${ }^{69}$ But it is precisely their private character that reveals something valuable about the privilege, even hubris, of those in the position to produce these images. From my personal experience I know that the pressures and risks in these situations can be considerable, and are relieved in a variety of ways. This can take the form of gallows humour, or incongruous light-heartedness, along with substance abuse and a certain amount of macho posturing. ${ }^{70}$ At the same time, there is the well-known phenomenon of "adrenaline addiction" among war correspondents, and sometimes aid workers. It is worth keeping in mind that these are people who chose to come to a conflict situation, and have the privilege of generally being able to leave as well. The privileges associated with the roles of 
these outside observers (or even "saviours") at a time of conflict can in some cases contribute to the abuses that have been well-documented in peacekeeping operations. ${ }^{71}$

The idea of a "shock" is prominent in Benjaminian conceptions of photography and history. Benjamin's idea of shock is primarily linked with the "assaults upon the subject associated with urban life and modern technologies", to the point that Benjamin would claim that "in a film, perception in the form of shocks was established as a formal principle". ${ }^{72}$ For Catherine Russell, this places shock within the realm of montage, as one of the techniques that interrupt "the 'flow' of images on which conventional historicism relies". ${ }^{73}$ But montage is also a technique of narrativisation, and for Doane, shock represents the threat of the illegible, the unassimilable, and in that sense is aligned with the contingent. ${ }^{74}$ Contingency is exactly the mark of the long take, and of raw rushes: the longer the camera runs, the greater the threat of something that interrupts narrative intention and cohesion. The shock of incongruity in the CNN and UNTV rushes therefore, is precisely aligned with their status as rushes, but this shock is also what interrupts the "flow" of the conventional audio-visual narrative of the Bosnian conflict.

\section{Conclusions}

The insights gleaned from the raw rushes in this case is an indication of the value, in historiographical terms, of the preservation of rushes of any conflict situation. First of all, the rushes allowed me to establish the presence of other cameras and crews, which opens up other avenues of research to pursue, and which is a clear indication of the highly mediated and performative nature of the event depicted in this footage. Secondly, the relative neglect of the front-line rushes in favour of a focus on the humanitarian relief story sets up the international aid workers as "saviours", and the local population as "victims" with little or no political agency, and leaves aside the question of the political aims the respective antagonists were fighting for. This speaks to an era in which Human Rights are only to be protected from violation, which ultimately 
favours the status quo, and which is powerless to address "facts on the ground" that have already been created. Finally, the incongruity of the "private rushes" included in the footage provide an unexpected insight into the pressures and the privileges the producers of these images were working under.

As my analysis has shown, the rushes captured during the siege of Mostar can be read to generate meanings "oblique, peripheral or even antagonistic to the text as understood". ${ }^{75}$ In my view, along with other "overlooked" elements within the rushes, they have the potential to evoke what the historian Eelco Runia has called "presence", described as "the unrepresented ways in which the past is present in the present". ${ }^{76}$ Runia locates this in metonymy: in the overlooked, taken-forgranted figures of speech that form a "presence in absence". ${ }^{77}$ There appears to be a particular affinity between this formulation of "presence" and the potentialities of the overlooked, taken-forgranted elements in rushes that would normally be left on the cutting room floor.

It must be said that this analysis is specific for the technological and institutional circumstances of the 1990s. As Fossati notes, audio-visual media are in continuous transformation, and at any time the media landscape consists of hybrid technologies. ${ }^{78}$ At the same time, the exponential rise in the production and distribution of moving images via camera phones and social media platforms has drastically changed our media ecology, producing vast, semi-structured online "collections" of moving images, in which largely random factors decide inclusion and exclusion, and which are all but impossible for humans to search comprehensively. ${ }^{79}$ If these can be called archives at all, they are a different type of archive than the commercial news archives I have described above, similarly hidden behind corporate firewalls, but largely opaque even to the corporations that own them, and run them by algorithm. The analysis of inclusion and exclusion, of presence and absence in these "archives" will be an urgent and fascinating subject for further study. 


\section{Notes}

1. "Bosniak" is the designation that was officially adopted in by the Bosnian parliament in 1994 to refer to Muslim Bosnians who were usually referred to as "Muslims" in the news media.

2. Laura Silber and Allan Little, Yugoslavia: Death of a Nation, Rev. and updated ed (New York, NY: Penguin Books, 1997), 297. Silber and Little, among others, blame the Vance-Owen plan for encouraging the conflict between Bosnian Croats and Bosniaks, as it appeared to reward ethnic cleansing and land-grabs by ethno-nationalist militias. This plan was partly reversed by the Washington Agreement of March 1994, in which the Bosnian Croat militias (under pressure from Croatia and the US) agreed to join the Bosnian government in a federal entity.

3. Orhan, Ševko, Eldin, Nedžad and Sead were soldiers in the ARBiH at the time, Dženana, Amar, Amila, Jasmin, Zlatko and Senada were civilians. They were interviewed between November 2017 and July 2019. I refer to my interlocutors in Mostar only by first name.

4. This quote is usually attributed to the American journalist Philip Graham, but variations on it were used earlier by others.

5. In searches within the context of my academic research I have found that much material that is available in these news archives is either absent or all but impossible to find in deposit archives. For example, in my search for moving images of Mostar in 1993 and 1994, the British Library index yielded no results, and the BFI's "BBC Programme Index" yielded only one documentary, while a search for "Mostar" in Getty Images (which handles the commercial BBC archive) yielded 20 BBC items between 19 and 30 August alone.

6. Jacques Derrida, Archive Fever, 9-10. As Derrida points out, the etymology of archive points us to the arkheion, the house of superior magistrates (archons) in Greek antiquity, where official documents are kept under the guardianship of these archons, who are accorded the hermeneutic right and competence to interpret those documents.

7. Michel Foucault, Archaeology of Knowledge (London: Routledge, 2002), 145-46.

8. The exception is the CNN Collection.

9. Trond Lundemo, "Archives and Technological Selection", Cinémas 24, no. 2-3 (2014): 17-18. For Lundemo, this is primarily a technological question, pointing out how analogue information gets lost by compression in the transfer of audio-visual information from analogue to digital formats.

10. Wolfgang Ernst, "Digital Memory and the Archive", Electronic Mediations vol 39 (Minneapolis, MN, Minneapolis: University of Minnesota Press, 2013): 81.

11. The Reuters archive was bought and sold multiple times among ITNSource, Pathé, and Getty Images. Adding to the complexity, archives can "handle" collections or other archives without owning them (Getty handles BBC, ITN and NBC collections but doesn't own the footage), and single items can contain material that has to be licenced through third parties. A truly comprehensive study of the various pressures and real-life practices in moving image archives would have to be large-scale, and is well beyond the scope of this study.

12. Matthew Butson, Vice-President of the Getty Images Hulton Archive, in an interview at the Hulton Archive in London about its preservation and digitisation policies, on 7 December 2021. 13. In my searches for news footage from the conflicts in Cyprus (1974) and in Bosnia-Herzegovina (1992-95), in the archives of AP, ITNSource and Getty Images, the great majority of entries would be analogue only. When requesting screeners from ITNSource for news items from Cyprus, I was asked to pay for transfers from $16 \mathrm{~mm}$ film. The items I paid for later showed up in digital form in the searchable interface of the archive. 
14. Giovanna Fossati, From Grain to Pixel the Archival Life of Film in Transition (Amsterdam: Amsterdam University Press, 2009): 13-17. Fossati argues that audio-visual media are in a state of continuous transformation, so the work of film preservation and restoration is also continuous. 15. This may well change for future generations with the current vogue for colourising black-andwhite archive footage by Peter Jackson, among others, perhaps most notably in David Shulman's Auschwitz Untold, which contains colourised footage of WW2 concentration camps.

16. Pierre Nora, Realms of Memory: The Construction of the French Past, trans. Arthur Goldhammer, vol. 1 (New York, NY: Columbia University Press, 1996): 2-3.; Aleida Assmann, Shadows of Trauma: Memory and the Politics of Postwar Identity (New York, NY: Fordham University Press, 2016): 21.; Aleida Assmann, "Transformations between History and Memory", Social Research: An International Quarterly 75, no. 1 (Spring 2008): 55-56. Assmann's “Transformations between History and Memory" also provides a useful overview of the relations between memory and history. 17. Eyal Sivan, Izkor: Slaves of Memory, Documentary (FR3, IMA Productions, Rhea Films, 1995). A striking example of this is provided in Sivan's film Izkor, in which Israeli schoolchildren of North African Jewish descent explain to the filmmaker their memories of the Holocaust.

18. Assmann, Shadows of Trauma, 22-28.

19. Mary Ann Doane, The Emergence of Cinematic Time: Modernity, Contingency, the Archive (Cambridge, MA.: Harvard University Press, 2002): 94, 172, 216.

20. Philip Rosen, Change Mummified: Cinema, Historicity, Theory (Minneapolis, MN: University of Minnesota Press, 2001): 115. The relation between historiography and narrative is highly contested and much commented on, but this falls outside the scope of this article.

21. Unfortunately, the same term in an academic context suggests a scholar researching film. However, Phil Clark has about 30 years of experience as a "film researcher" for the BBC and for independent television documentary productions.

22. Based on an online interview I conducted with Phil Clark on 19 August 2020.

23. In an interview conducted on 7 December 2021.

24. Assmann, Shadows of Trauma, 22-28.

25. Lamija Grebo, "Bosnian Serb Decree Rejecting Genocide Denial Law Sparks Uncertainty",

Balkan Insight, 13 October 2021, https://balkaninsight.com/2021/10/13/bosnian-serb-decree-

rejecting-genocide-denial-law-sparks-uncertainty/; Srecko Latal, "Radical Rhetoric in Bosnia Revives Fears of New Conflict", Balkan Insight, 5 October 2021,

https://balkaninsight.com/2021/10/05/radical-rhetoric-in-bosnia-revives-fears-of-new-conflict/.

Remarkably, what has been described as the "Mostarisation" of Bosnia-Herzegovina refers to the fact that the strict allocation of local government positions along ethnic lines in Mostar has paralysed its municipal politics for many years.

26. Dai Vaughan, For Documentary: Twelve Essays (Berkeley, CA: University of California Press, 1999): 80.

27. Doane, The Emergence of Cinematic Time, 104-5; Pier Paolo Pasolini, "Observations on the Long Take", October 13 (1980): 5-6, https://doi.org/10.2307/3397696.

28 Georges Didi-Huberman, Images in Spite of All: Four Photographs from Auschwitz, trans. Shane B. Lillis (Chicago, IL: The University of Chicago Press, 2003): 124.

29. This broad field of study is beyond the scope of this article, but significant contributions were made by Shoshana Felman and Dori Laub, Cathy Caruth, and Paul Antze among others.

30. Forensic Architecture, The Bombing Of Rafah: Black Friday, forensic-architecture.org, 2015, https://forensic-architecture.org/investigation/the-bombing-of-rafah . 
31. What is known as Standard Definition (SD) was the standardised resolution for video and television, which was 480x640 pixels in countries using the NTSC standard, and 576x768 pixels in countries using PAL or SECAM standards.

32. Because this connection existed there is still some contention as to whether the siege of Mostar was a real siege. My position is that for regular residents of Mostar this certainly amounted to a siege (after all, Sarajevo was also tenuously connected to the outside world with a tunnel under the airport). 33. In a calculated and well-coordinated action, a large group of mostly women and children surrounded the vehicles of the UN convoy, demanding a permanent presence of the UN in the enclave. Part of the understanding was that such presence would diminish the threat of random mortar attacks, and there was widespread sympathy in the UN for their position.

34. As mentioned above, Getty "handles" but doesn't own the BBC, ITN and NBC material.

35. One of the online items was mislabelled: its description starts "CMS Serbian militia leader intvwd" whereas "Adnan" is a Muslim name and indeed the voice-over quotes him saying that he "lost 100 men for every meter lost to the Serbs", so he clearly belonged to the ARBiH. Mislabelling is not uncommon in commercial archives: often descriptions are second or third-hand, and based on rough $\log$ notes from the field.

36. I requested and indeed received especially digitised screeners, but to the best of my knowledge those were not made available via the CNN online search function. This is another example of the "digitisation on demand" model of most news archives.

37. The camera in the first convoy was operated by Simo Vaatainen (who was not a professional cameraman), and the one in the second convoy by Will Stebbins. I edited the 10-minute video press release at the end of August 1993 with Stebbins.

38. The video unit of $P \& I$ was significantly restructured and expanded to become its own department as "UNTV" after I left early in 1994. Of the dozens of reels of rushes we shot in the time before the expansion, only a handful survived in the collection at the IWM, illustrating how easily rushes from a conflict situation can get lost.

39. United Nations, MOSTAR Rushes UNT 933/01, United Nations 1993.

40. United Nations, MOSTAR Rushes UNT 933/01; Brent Sadler and Mark Biello, MOSTAR CNN Rushes Tape No. FC7904, CNN Collection 1993.

41. Bernard Stiegler, Technics and Time: Disorientation (Stanford, CA: Stanford University Press, 2008): 116.

42. From interviews with Orhan and Ševko, and also from conversations with Jimmi James.

43. Jeremy Bowen, War Stories, Reissue edition (Simon \& Schuster UK, 2014): 180-84; Jeremy Bowen, Feature on Mostar for BBC News 6pm, 27 August 1993; Eamonn Matthews and Jeremy Bowen, Unfinished Business, 1993, https://www.youtube.com/watch?v=rkS8YlASVzk . Bowen would return less than a month later with a BBC documentary crew, staying for about two weeks, during which time many of the "usual conditions" in the enclave had resumed. As a result, the conditions depicted in this documentary, titled Unfinished Business, are closer to the conditions experienced throughout the siege by the population of east Mostar, and the film is still highly regarded locally.

44. Bowen is again the exception by including a brief scene of the centralised kitchen, and mentioning the impressive level of organisation in the enclave.

45. Brent Sadler, MOSTAR AID CNN Edited Report, CNN 1993. The medicines were unloaded at the end of the day, but this is shown at the beginning of the report to establish the humanitarian purpose of the convoy.

46. Brent Sadler, MOSTAR MUSLIMS CNN Edited Report, CNN 1993. The hospital shots and the interview with Dr Mujic are not in the CNN rushes I have, and are probably from two reels that I believe to be missing from what I received: the tape numbers of the rushes start from FC7901; after 
the arrival of the crew in east Mostar (at the end of tape FC7902), the number FC7903 is skipped and tape FC7904 starts with a shot right on the frontline. In addition, FC7904 ends just before the moment the medical aid is unloaded by the hospital, an event that is included in the MOSTAR AID report. There is a tape FC7905, dated 8/21/1993, but this must be mislabelled: it depicts the evacuation of wounded children that happened after 25 August. It is not clear if the original reels still exist. 47. Carole Walker, Feature on Mostar for BBC News_lib Cu-229070. 23 August 1993, BBC Broadcast Archives.

48. 'BHS' stands for Bosanska-Hrvatska-Srpska, and is the current politically neutral designation of the language formerly known as Serbo-Croatian.

49. Brent Sadler and Mark Biello, MOSTAR CNN Rushes Tape No. FC7904. A "piece to camera" is a technical term for a statement by the reporter addressed directly to the viewer.

50. Walker, Feature on Mostar for BBC News_lib Cu-229070.

51. Silber and Little, Yugoslavia, 208.

52. In 2019 I collaborated with Jimmi James and Smajo Bešo on a small online survey of current and former Mostar residents based on samples of untransmitted rushes posted by James. In the 44 responses, the term "Croat" was mentioned five times, the term "fascist" four times, and "Ustashe" three times. "Tito" and "Yugoslavia" were invoked twice each, while "Bosniak" and "Muslim" were mentioned only once each. I cited the results of this survey as part of a presentation of my research at the conference Why Remember? in Sarajevo on 9 July 2019, but otherwise they have not been published.

53. In February 2018, I attended the commemoration of Partisan fighters who fell during the liberation of Mostar from fascism in the Second World War, at the Partisan Memorial Cemetery in West Mostar. It was attended by a large crowd of people, replete with Yugoslav-era flags. The event was organised by the Association of Anti-Fascist Heroes and Martyrs, a Tito-era veterans association which continues its activities in Bosnia-Herzegovina. The Partisan Memorial Cemetery, even though it has the status of a national monument, is regularly vandalised with graffiti of swastikas and Ustashe symbols and slogans.

54. Catherine Baker, Race and the Yugoslav Region: Postsocialist, Post-Conflict, Postcolonial? (Manchester University Press, 2018): 128, https://doi.org/10.7765/9781526126610.; V. P. Gagnon, The Myth of Ethnic War: Serbia and Croatia in the 1990s (Ithaca, NY: Cornell University Press, 2004). Gagnon attributes the ubiquity of the "ancient hatred thesis" mainly to the influence of Robert Kaplan's book Balkan Ghosts.

55. Maria Todorova, Imagining the Balkans (Oxford: Oxford University Press, 2009).

56. Darryl Li, The Universal Enemy: Jihad, Empire, and the Challenge of Solidarity, Stanford Studies in Middle Eastern and Islamic Societies and Cultures (Stanford, CA: Stanford University Press, 2020): 64 .

57. Robert Meister, After Evil: A Politics of Human Rights, Columbia Studies in Political Thought/Political History (New York, NY: Columbia University Press, 2011): 7-8.

58. cf. Eyal Weizman, The Least of All Possible Evils: Humanitarian Violence from Arendt to Gaza (London: Verso, 2011).

59. Samantha Power, A Problem from Hell: America and the Age of Genocide (William Collins, 2021), 306. On the issue of false equivalence, see also Helen Walasek et al., Bosnia and the Destruction of Cultural Heritage (Routledge, 2016): 6-7.

60. Power, A Problem from Hell, 307-8.

61. Matthew W. Hughey, "The White Savior Film and Reviewers' Reception". Symbolic Interaction 33, no. 3 (2010): 475-96. Lawrence of Arabia (1962) and Dances with Wolves (1990) are notorious 
examples, but Avatar (2009) also falls squarely into the genre, showing that "non-white" can cover a wide range of Others.

62. Baker, Race and the Yugoslav Region, 127-32, 146. Baker shows how local objections to the presence of non-white peacekeepers was often tinged with racism.

63. Milica Bakić-Hayden, "Nesting Orientalisms: The Case of Former Yugoslavia", Slavic Review 54, no. 4 (1995): 917-31, https://doi.org/10.2307/2501399.

64. Baker, Race and the Yugoslav Region, 129.

65. Brent Sadler and Mark Biello, MOSTAR CNN Rushes Tape No. FC7901, 1993.

66. United Nations, MOSTAR Rushes UNT 933/01.

67. United Nations, MOSTAR Rushes UNT 933/02, 1993.

68. I certainly was reminded with a shock that the "psy-ops" punchline was indeed a running gag among some of my colleagues, along with an only half-joking wager on who in the office was the CIA operative.

69. I requested and received the CNN rushes as "screeners", which implies that in principle the footage is available to be licenced for use in a documentary film production. I requested and received copies of the UNTV footage from the IWM archive specifically for academic research.

70. Bowen, War Stories, 183. Tellingly, Bowen describes CNN cameraman Mark Biello as "a nice guy, a big drinker who called himself Mad Dog and did everything he could to become a journalistic legend".

71. For an overview see Ragnhild Nordås and Siri C. A. Rustad, 'Sexual Exploitation and Abuse by Peacekeepers: Understanding Variation', International Interactions 39, no. 4 (1 September 2013): 511-34, https://doi.org/10.1080/03050629.2013.805128. Some allegations of sexual abuse by UN soldiers in Mostar were related to me during my interviews, but as far as I am aware, no formal accusations have been made against the Spanish Battalion that was operational there at the time. Other forms of the abuse of power by UN peacekeeping forces in Haiti are powerfully documented in the film It Stays With You: Use of Force by UN Peacekeepers in Haiti, by Cahal McLaughlin and Siobhán Wills.

72. Doane, The Emergence of Cinematic Time, 13.; Walter Benjamin, Illuminations, New ed. (London: Fontana, 1992), 175.

73. Catherine Russell, Archiveology: Walter Benjamin and Archival Film Practices, Camera Obscura Books (Durham, NC: Duke University Press, 2018), 28.

74. Doane, The Emergence of Cinematic Time, 14.

75. Vaughan, For Documentary, 80.

76. Eelco Runia, "Presence", History and Theory 45, no. 1 (2006): 1.

77. Runia, 20.

78. Fossati, From Grain to Pixel the Archival Life of Film in Transition, 19-20.

79. Lundemo, "Archives and Technological Selection", 22.

\section{Bibliography}

Assmann, Aleida. Shadows of Trauma: Memory and the Politics of Postwar Identity. New

York, NY: Fordham University Press, 2016. 
_- - "Transformations between History and Memory". Social Research: An International Quarterly 75, no. 1 (Spring 2008): 49-72.

Baker, Catherine. Race and the Yugoslav Region: Postsocialist, Post-Conflict, Postcolonial? Manchester University Press, 2018. https://doi.org/10.7765/9781526126610.

Bakić-Hayden, Milica. "Nesting Orientalisms: The Case of Former Yugoslavia". Slavic Review 54, no. 4 (1995): 917-31. https://doi.org/10.2307/2501399.

Benjamin, Walter. Illuminations. New ed. London: Fontana, 1992.

Bowen, Jeremy. War Stories. Reissue edition. Simon \& Schuster UK, 2014.

Didi-Huberman, Georges. Images in Spite of All: Four Photographs from Auschwitz.

Translated by Shane B. Lillis. Chicago, IL: The University of Chicago Press, 2003.

Doane, Mary Ann. The Emergence of Cinematic Time: Modernity, Contingency, the Archive. Cambridge, MA: Harvard University Press, 2002.

Ernst, Wolfgang. Digital Memory and the Archive. Electronic Mediations; v. 39.

Minneapolis, MN: University of Minnesota Press, 2013.

Fossati, Giovanna. From Grain to Pixel the Archival Life of Film in Transition. Amsterdam: Amsterdam University Press, 2009.

Foucault, Michel. Archaeology of Knowledge. London: Routledge, 2002.

Gagnon, V. P. The Myth of Ethnic War: Serbia and Croatia in the 1990s. Ithaca, NY: Cornell University Press, 2004.

Grebo, Lamija. "Bosnian Serb Decree Rejecting Genocide Denial Law Sparks Uncertainty". Balkan Insight, 13 October 2021. https://balkaninsight.com/2021/10/13/bosnian-serbdecree-rejecting-genocide-denial-law-sparks-uncertainty/.

Hughey, Matthew W. "The White Savior Film and Reviewers' Reception". Symbolic Interaction 33, no. 3 (2010): 475-96. https://doi.org/10.1525/si.2010.33.3.475. 
Latal, Srecko. "Radical Rhetoric in Bosnia Revives Fears of New Conflict". Balkan Insight, 5 October 2021. https://balkaninsight.com/2021/10/05/radical-rhetoric-in-bosniarevives-fears-of-new-conflict/.

Li, Darryl. The Universal Enemy: Jihad, Empire, and the Challenge of Solidarity. Stanford Studies in Middle Eastern and Islamic Societies and Cultures. Stanford, CA: Stanford University Press, 2020.

Lundemo, Trond. "Archives and Technological Selection". Cinémas 24, no. 2-3 (2014): 1739. https://doi.org/10.7202/1025147ar.

Meister, Robert. After Evil: A Politics of Human Rights. Columbia Studies in Political Thought/Political History. New York, NY: Columbia University Press, 2011.

Nora, Pierre. Realms of Memory: The Construction of the French Past. Translated by Arthur Goldhammer. Vol. 1. New York, NY: Columbia University Press, 1996.

Nordås, Ragnhild, and Siri C. A. Rustad. "Sexual Exploitation and Abuse by Peacekeepers: Understanding Variation". International Interactions 39, no. 4 (1 September 2013): 511-34. https://doi.org/10.1080/03050629.2013.805128.

Pasolini, Pier Paolo. "Observations on the Long Take". October 13 (1980): 3.

\section{https://doi.org/10.2307/3397696.}

Power, Samantha. A Problem from Hell: America and the Age of Genocide. Glasgow: William-Collins, 2021.

Rosen, Philip. Change Mummified: Cinema, Historicity, Theory. Minneapolis, MN: University of Minnesota Press, 2001.

Runia, Eelco. "Presence". History and Theory 45, no. 1 (2006): 1-29.

Russell, Catherine. Archiveology: Walter Benjamin and Archival Film Practices. Camera Obscura Book. Durham, NC: Duke University Press, 2018. 
Silber, Laura, and Allan Little. Yugoslavia: Death of a Nation. Rev. and Updated ed. New York, NY: Penguin Books, 1997.

Stiegler, Bernard. Technics and Time: Disorientation. Stanford, CA: Stanford University Press, 2008.

Todorova, Maria. Imagining the Balkans. Oxford: Oxford University Press, 2009.

Vaughan, Dai. For Documentary: Twelve Essays. Berkeley, CA: University of California Press, 1999.

Walasek, Helen, contributions by Richard Carlton, Amra Hadžimuhamedović, Valery Perry, and Tina Wik. Bosnia and the Destruction of Cultural Heritage. New York and London: Routledge, 2016.

Weizman, Eyal. The Least of All Possible Evils: Humanitarian Violence from Arendt to Gaza. London: Verso, 2011.

\section{Filmography}

Bowen, Jeremy. Feature on Mostar for BBC News 6pm_ANBH739R, 27 August 1993. BBC Broadcast Archives

Bowen, Jeremy and Matthews, Eamonn. Unfinished Business, 4 November 1993. BBC Broadcast Archives. https://www.youtube.com/watch?v=rkS8Y1ASVzk

Forensic Architecture. The Bombing of Rafah: Black Friday. forensic-architecture.org, 2015. https://forensic-architecture.org/investigation/the-bombing-of-rafah.

Getty Images. 74 Mostar Videos and HD Footage, web impression, accessed 10 December 2021. https://www.gettyimages.co.uk/videos/mostar?assettype=film\&begindate=1993$\underline{08-19 \& e n d d a t e=1993-08-}$

$\underline{30 \& \text { offlinecontent }=\text { include } \& \text { phrase }=\text { mostar } \& \text { recency }=\text { daterange } \& \text { sort=best } \& \text { license }=r f}$, $\underline{\mathrm{rr}}$ 
McLaughlin, Cahal and Wills, Siobhán. It Stays With You: Use of Force by UN Peacekeepers in Haiti, 2018. https://vimeo.com/409176307

Sadler, Brent. MOSTAR AID CNN Edited Report 90573913, CNN Collection 1993. MOSTAR MUSLIMS CNN Edited Report 90574044, CNN Collection 1993.

Sadler, Brent, and Biello, Mark. MOSTAR CNN Rushes Tape No. FC7901, CNN Collection 1993.

_. MOSTAR CNN Rushes Tape No. FC7904, CNN Collection 1993.

Sivan, Eyal. Izkor: Slaves of Memory. Documentary. FR3, IMA Productions, Rhea Films, 1995.

United Nations. MOSTAR Rushes IWM UNT 933/01, United Nations 1993.

—. MOSTAR Rushes IWM UNT 933/02, United Nations 1993.

Walker, Carole. Feature on Mostar for BBC News_lib Cu-229070, 23 August 1993. BBC Broadcast Archives.

\section{Author Biography}

Lennaart van Oldenborgh is a practice-based $\mathrm{PhD}$ candidate in the Media, Communications and Cultural Studies department at Goldsmiths, University of London. In 1993-94 he worked for the UN mission in the former Yugoslavia (UNPROFOR), before settling in London in 1997 , where he established himself as a documentary film editor. He edited the 2018 BAFTA winning documentary Basquiat: Rage to Riches for BBC Studios. He co-directed the featurelength documentary film Bitter Lemons with Adnan Hadzi, about the post-conflict situation in Cyprus, which premiered at the Solothurn Film Festival in 2014, and published Performing the Real, in The State of the Real (2007, I.B. Taurus). From 2017 to 2019 he taught film theory and tactical media as Associate Lecturer at Goldsmiths, University of London. 